\title{
PROFIL KROMATOGRAFI LAPIS TIPIS MINYAK ATSIRI SEREH (Cymbopogon citratus)
}

\author{
Rani Prabandari \\ Sekolah Tinggi Harapan Bangsa Purwokerto
}

\begin{abstract}
Abstrak.
Telah diisolasi rhodinol dari minyak sereh. Isolasi minyak sereh dilakukan dengan menggunakan metode destilasi. Sampel yang digunakan sereh umur panen 6 bulan dan 9 bulan. Fase Diam yang digunakan Plat KLT slika gel F254 dengan ukuran 2 x $10 \mathrm{~cm}$ dan fase gerak yang digunakan adalah Toluen:Etil Asetat (93:7). Hasil profil HRf Kromatografi Lapis Tipis yang diperoleh untuk percobaan I (sereh usia panen 6 bulan) berturutturut 32, 77, 87 dan Percobaan II (sereh usia panen 9 bulan) berturut-turut 25, 73, 81.
\end{abstract}

Abstract.

Rhodinol has been isolated from citronella oil. Isolation of lemongrass oil is done by using the distillation method. Samples used were citronella harvested for 6 months and 9 months. Silent phase used TLC plate slika gel F254 with a size of $2 \times 10 \mathrm{~cm}$ and the mobile phase used was Toluen: Ethyl Acetate (93: 7). Results of Thin Layer Chromatography HRF profile obtained for experiment I (citronella harvesting age 6 months) 32, 77, 87 and Experiment II (lemongrass harvest age 9 months) respectively 25, 73, 81.

\section{PENDAHULUAN}

Indonesia ditengarai sebagai salah satu negara penghasil minyak atsiri yang cukup penting di dunia. Alam Indonesia sangat kaya tumbuh-tumbuhan mengandung minyak atsiri. Minyak atsiri dapat dihasilkan dari berbagai bagian tanaman seperti akar, batang, daun, bunga, atau buah. Jenis tanaman penghasil minyak atsiri ada 50-200 spesies. Di Indonesia terdapat sekitar 40 jenis tanaman penghasil minyak atsiri. Salah satu tanaman penghasil minyak atsiri adalah sereh (Taufiq, Tuhana, 2008).

Minyak atsiri dikenal juga dengan nama minyak terbang, minyak eteris, essential oil atau volatile oil, yang dihasilkan oleh tanaman. Minyak atsiri mudah menguap pada suhu kamar, mempunyai rasa getir, berbau wangi sesuai dengan bau tanaman penghasilnya (Ketaren, S, 1985).

Minyak sereh wangi, adalah salah satu minyak atsiri yang merupakan komoditi di

Viwa Medika | EDISI KHUSUS/SERI 1/ NOVEMBER/2017 
sektor agribisnis memiliki pangsa pasar yang baik dan berdaya saing kuat di pasaran luar negeri. Minyak sereh wangi tersusun dari tiga komponen utama yang dapat memberikan aroma yang lembut sehingga memiliki nilai jual sangat tinggi. Ketiga komponen minyak sereh wangi yaitu sitronelal, sitronelol dan geraniol dimana sitronelol dan geraniol dalam perdagangan dikenal dengan rhodinol.

Ketiga senyawa tersebut dalam pemanfaatannya digunakan untuk bahan baku industri fragrance, industri farmasi dan keperluan pembuatan kosmetik sehingga meningkatkan nilai jualnya. Ketiga komponen ini dapat diisolasi dengan cara destilasi. Khususnya sitronelol dan geraniol hasil isolasinya masih dalam bentuk campuran yang dikenal dengan rhodinol. Kedua senyawa ini memiliki struktur yang mirip dan hanya berbeda pada jumlah ikatan rangkapnya. Minyak sereh yang dihasilkan dengan cara penyulingan daun sereh mengandung kurang dari $0,5-1,2$ persen minyak. Bahan kimia yang terpenting dalam minyak sereh adalah persenyawaan aldehid dengan nama sitronellal dan persenyawaan alkohol disebut geraniol (Ketaren, S, 1985).

\section{METODOLOGI PENELITIAN}

\section{Alat dan Bahan}

Alat-alat yang digunakan pada penelitian ini adalah alat-alat gelas kimia yang umum digunakan di laboratorium, bejana KLT, lampu UV, neraca analitik, satu set alat destilasi, etil asetat $(\mathrm{CH} 3 \mathrm{COOC} 2 \mathrm{H} 5)$, toluen (C7H8), aquadest, plat KLT slika gel F254.

\section{Prosedur Penelitian}

Sebanyak $500 \mathrm{~mL}$ minyak sereh dimasukkan dalam labu alas bulat, berkapasitas 1L yang dilengkapi dengan stirer dan termometer pada labu. Kemudian labu destilasi alas bulat tersebut dihubungkan dengan kolom vigreux kemudian dipasang menjadi satu set alat destilasi.

Plat KLT slika gel F254 dengan ukuran 2 x $10 \mathrm{~cm}$ disiapkan, kemudian sampel ditotolkan pada plat KLT dengan menggunakan pipa kapiler. Plat KLT dibiarkan sesaat, kamudian dimasukkan ke dalam bejana KLT yang sudah jenuh dengan menggunakan pelarut toluen : etil asetat (93:7) (Wagner, 1984), sampai terlihat noda noda. 


\section{HASIL DAN PEMBAHASAN}

Kromatografi adalah salah satu metode pemisahan komponen dalam suatu sampel dimana komponen tersebut didistribusikan di antara dua fasa yaitu fasa gerak dan fasa diam. Fasa gerak adalah fasa yang membawa cuplikan, sedangkan fasa diam adalah fasa yang menahan cuplikan secara efektif (Sastrohamidjojo, 1991).

Analisis suatu senyawa dalam KLT biasanya dilakukan dengan dibandingkan terhadap senyawa standarnya. Pengamatan yang lazim berdasarkan pada kedudukan dari noda relatif terhadap batas pelarut yang dikenal sebagai harga $\mathrm{Rf}$ (Retardation factor) yang didefinisikan sebagai berikut $: \mathrm{Rf}=$ jarak komponen yang begerak dibagi Jarak pelarut yang bergerak. Harga Rf yang telah dihitung dan warna noda dibandingkan dengan data sekunder dari literature.

Pola noda hasil KLT menggunakan komposisi eluen toluen : etil asetat (93:7) menunjukkan sampel telah terelusi tetapi antara noda belum terpisah dengan baik. Sehingga, kepolaran dari campuran eluen perlu ditingkatkan untuk penelitian lanjutan.

Tabel 1. Hasil Analisis KLT Sampel Minyak Atsiri Sereh dengan Eluen Toluen:Etil Asetat (93:7)

\begin{tabular}{|c|c|c|c|}
\hline Percobaan & $\begin{array}{c}\text { Jarak rambat } \\
\text { fase Gerak }\end{array}$ & Nilai Rf & Nilai HRf \\
\hline I & $8 \mathrm{~cm}$ & a. 0,32 & 32 \\
\hline & & b. 0,77 & 77 \\
\hline & & c. 0,87 & 87 \\
\hline II & $8 \mathrm{~cm}$ & a. 0,25 & 25 \\
\hline & & b. 0,73 & 73 \\
\hline & & c. 0,81 & 81 \\
\hline
\end{tabular}

dapat menggunakan cara lain seperti

Minyak atsiri merupakan senyawa, ekstraksi menggunakan pelarut organik atau yang pada umumnya berujud cairan, yang dengan cara dipres (Hardjono, S.,2004). Pada diperoleh dari bagian tanaman, akar, kulit, umumnya minyak atsiri larut dalam etanol batang, daun, buah, biji, maupun dari bunga atau pelarut organik polar lain dan dengan cara penyulingan. Meskipun kelarutannya akan menurun jika kadar etanol kenyataan untuk memperoleh minyak atsiri kurang dari $70 \%$. Bila minyak atsiri Vwea Medika | EDISI KHUSUS/SERI 1/ NOVEMBER/2017 
mengandung fraksi terpen (senyawa non polar) dalam jumlah besar maka kelarutannya dalam etanol relatif kecil. Kegunaan minyak atsiri bagi tanaman sendiri untuk menarik serangga yang membantu proses penyerbukan, sebagai cadangan makanan, untuk mencegah kerusakan tanaman oleh serangga dan mempengaruhi proses transpirasi. Dalam industri sering digunakan sebagai zat tambahan dalam sediaan kosmetika, obat, makanan, rokok dan sebagainya. Selain itu minyak atsiri digunakan sebagai obat anti kuman dan kapang.

Fase Diam yang digunakan Plat KLT slika gel F254 dengan ukuran 2 x $10 \mathrm{~cm}$ dan fase gerak yang digunakan adalah Toluen:Etil Asetat (93:7). Hasil HRf Kromatografi Lapis Tipis yang diperoleh untuk percobaan I (sereh usia panen 6 bulan) berturut-turut 32, 77, 87 dan Percobaan II (sereh usia panen 9 bulan) berturut-turut 25, 73, 81 .

\section{KESIMPULAN}

Hasil HRf Kromatografi Lapis Tipis yang diperoleh untuk percobaan I (sereh usia panen 6 bulan) berturut-turut 32, 77, 87 dan
Percobaan II (sereh usia panen 9 bulan) berturut-turut $25,73,81$.

\section{DAFTAR PUSTAKA}

E. Guenther, Minyak Atsiri Jilid I. Penerjemah Ketaren S. Jakarta : Universitas Indonesia Press (1987).

Ketaren, S., 1987, Pengantar Teknologi Minyak Atsiri, PN. Balai Pustaka, Jakarta, hal 49-67,113, 239-259.

Sastrohamidjojo, H., 2004, Kimia Minyak Atsiri, Gadjah Mada University Press, Yogyakarta, Hal : 13-14.

Sastrohamidjojo, H., 1991, Spektroskopi, Liberty, Yogyakarta, Hal : 1-97, $163-$ 184

Taufiq, Tuhana. 2008. Menyuling Minyak Atsiri. Yogyakarta: Citra Aji Parama. hal: 2, 6, 27, 29, 40 